\title{
PERSONAL ORNAMENTS FROM CHALCOLITHIC GÜLPINAR, NORTH-WEST ANATOLIA
}

\author{
Emma L. BAYSAL* \\ Çilem YAVŞAN**
}

Keywords: Personal ornaments $\bullet$ Marine shell $\bullet$ Stone $\bullet$ Clay $\bullet$ Chalcolithic $\bullet$ North-west Anatolia

\begin{abstract}
The site of Gülpinar, located in the Troad in north-west Anatolia has revealed settlements of the Early and Middle Chalcolithic periods (late $6^{\text {th }}$ to mid- $5^{\text {th }}$ millennia BC). Among the artefacts recovered during the excavation is a small number of personal ornaments. This article provides descriptions of the artefacts and considers how they fit into the wider ornamentation practices of prehistory. There are few published items of ornamentation from the period during which Gülpınar was inhabited so direct comparators are in relatively short supply. However, considering earlier developments in ornamentation practices and evidence from a broad region it is possible to draw some conclusions about the choices made by the site's inhabitants.
\end{abstract}

\section{GÜLPINAR, KUZEYBATI ANADOLU, KALKOLİTİK DÖNEM KİŞİSEL SÜS EŞYALARI}

\author{
Anahtar Kelimeler: Kişisel Süs Esyalar $・$ Deniz Kabuğu $\bullet$ Taş $\bullet$ Kil $\bullet$ Kalkolitik $\bullet$ Kuzeybatı Anadolu
}

Özet: Kuzeybatı Anadolu'da, Biga yarımadasında bulunan Gülpınar'da, Erken ve Orta Kalkolitik dönem (M.Ö. geç 6. - orta 5. bin) yerleşimleri ortaya çıkarılmıştır. Kazılar sırasında ortaya çıkarılan eserler arasında az sayıda kişisel süs eşyası bulunmaktadır. Bu makale, eserlerin açıklamalarını sağlamakta ve bunların tarih öncesi döneme ait daha geniş alanda süsleme pratiğindeki uygulamalara nasıl uyum sağladığ1 konusunu ele almaktadır. Gülpınar'da açı̆̆a çıkarılan döneme ait yayımlanmış ve karşılaştırılabilecek kapasitede az sayıda süs eşyası vardır, bu nedenle doğrudan karşılaştırmalar nispeten yetersizdir. Bununla birlikte, süsleme pratiği uygulamalarındaki önceki gelişmeler ve daha geniş bir bölgeden gelen kanıtlar dikkate alındığında, yerleşimde oturanlar tarafından yapılan bu konudaki tercihler hakkında bazı sonuçları çıkarmak mümkündür.

\footnotetext{
* Doç. Dr. Emma L Baysal, Ankara Üniversitesi, Dil ve Tarih-Coğrafya Fakültesi, Arkeoloji Bölümü, Ankara, e-posta: elbaysal@ankara.edu.tr ORCID: 0000-0002-9804-2799

** Öğretim Görevlisi Dr. Çilem Yavşan, Çanakkale Onsekiz Mart Üniversitesi, Çanakkale Uygulamah Bilimler Fakültesi, Mǚrecilik. ve Kültürel Miras Yönetimi, Canakekale, e-posta: cilemyavsan@comu.edu.tr
}

ORCID ID: 0000-0003-1907-570X 


\section{Introduction}

The Chalcolithic of western and north-western Anatolia remains an enigmatic and under-researched period for which few sites have been excavated and the understanding of different phases is sketchy at best. Evidence relating to the Middle Chalcolithic, particularly of the coastal portion of western Anatolia is therefore important in contributing to our understanding of the complex relationship between this Aegean-facing region, the Aegean islands and inland western Anatolia ${ }^{1}$. The prehistoric settlement of Gülpinar, which takes its name from a synonymous village nearby, was identified beneath the remains of the Greek and Roman Sanctuary of Apollo Smintheus (Smintheion). The Early Chalcolithic (phase II) and Middle Chalcolithic (phase III) periods are the two main occupational phases that enhance our knowledge of the western Anatolian littoral during the Chalcolithic. Among the artefacts recovered was a small group of personal ornaments made from shell, stone and clay, some of the very few examples of personal ornamentation associated with the period. In this article these ornaments are evaluated in the light of known ornamentation practices with the hope of facilitating a better understanding of the little-known artefacts of the periods in question.

\section{The site of Gülpınar}

The prehistoric site of Gülpınar, which was first identified by J. Seeher in the $1980 \mathrm{~s}^{2}$, was later excavated between

\footnotetext{
1 Takaoğlu - Özdemir 2018.

2 Seeher 1987.

${ }^{3}$ Takaoğlu - Özdemir 2018, 480.

${ }_{4}^{4}$ Takaoğlu - Özdemir 2018, 481.
}

2004 and 2013 by a small team put together by $\mathrm{T}$. Takaoğlu as part of the Smintheion/Gülpinar excavations led by Prof. Coşkun Özgünel from Ankara University $^{3}$. The site is located $1 \mathrm{~km}$ from the Aegean coast at an elevation of $60 \mathrm{~m}$ above sea level in the Troad region of north-west Anatolia (Figs 1 and 2). Most of the excavated remains of the settlement date to the Early Chalcolithic 2 and Middle Chalcolithic periods, the former equating to approximately $5320-4940 \mathrm{BC}$ and the latter to 4930 - 4450/4300 BC meaning that it overlapped culturally and temporally with the local Kumtepe IA/Beşik-Sivritepe cultural horizon ${ }^{4}$. The two phases show continuity of occupation, the architecture consists of rectilinear structures, courtyards and corridors as well as food preparation areas and hearths. Phase III was built on top of phase II after some degree of levelling, the houses were well equipped for food storage, preparation and cooking ${ }^{5}$.

The ceramics of phases II and III bear significant resemblance to those at Beşik-Sivritepe, particularly the pattern burnished wares and incised pattern wares ${ }^{6}$. Symbolism is attested in anthropomorphic and zoomorphic ceramic handles, the former include details such as perforations for earrings as well as possible depiction of tears being shed ${ }^{7}$. The ceramics do not show a dramatic change between phases II and III, instead there is variation in types and sizes, with more large vessels and semi coarse wares characterising the later level and suggesting an

\footnotetext{
5 Takaoğlu - Özdemir 2018, 481.

${ }^{6}$ Takaoğlu - Özdemir 2018, 483-4.

7 Takaoğlu - Özdemir 2018, 485.
} 
emphasis on practical day-to-day activities $^{8}$. Several burials show that while grave gifts were sometimes present, burials were generally lacking in elaboration?

Overall, based on materials and artefacts including, for example, obsidian, copper, marble and jadeite recovered during the excavations, Gülpınar shows significant links with both the Aegean and inland Anatolia ${ }^{10}$. Here we explore how the small assemblage of personal ornaments might help us to situate the site in its wider temporal and spatial context.

\section{Shell Beads}

Shells were the most widely used raw material in the manufacture of personal ornaments in prehistory, with use starting in the Palaeolithic. The position of Gülpinar close to the coast means that marine shells were readily available and easy to procure, and indeed came to the site as part of food provision for the inhabitants. The small number of marine shell ornaments from Gülpınar are made up of a combination of highly worked items and expediently produced or serendipitously employed shells (Figs. 3-4). The several highly worked specimens were possibly partly reliant on natural processes prior to procurement for their naturally rounded form. A flat ring made from Glycymeris sp. (Figs. 3-4: 1) was probably produced from a piece of water worn shell with a large central hole abraded rather than drilled into it. The end result was probably a ring form, all edges were rounded, although it is now broken, about $60 \%$ is preserved. The shape is quite uneven, and the surface is very smooth. A

${ }^{8}$ Takaoğlu - Özdemir 2018, 486.

9 Takaoğlu - Özdemir 2018, 487. second example of the use of Glycymeris sp. (Figs. 3-4: 2) is a very smooth piece of the lip area from a large shell. It appears to have been shaped from a water worn piece. A perforation was made from both sides using a small drill (probably chipped stone). The surface is so smooth that there is no remaining sign of working marks. The shape is somewhat reminiscent of a tooth, curved, narrow at one end and wider at the other, and this may have influenced the choice of the shell.

A Mediterranean mussel shell (Mytilus galloprovincialis) with heavily worn surfaces (Figs. 3-4: 3) was perforated close to the umbo using abrasion along the length of the shell in combination with rotary drilling to produce the hole. The resulting perforation is significantly worn and it is clear that it was used after manufacture. The outer surface is completely missing leaving only white mother of pearl visible. Although there are fresh breaks, the intact natural edges are also quite rough without signs of wear. A naturally water worn Cerithium vulgatum shell (Figs. 3-4: 4) with a hole near the aperture seems to have been strung producing a very intense polish around the edges of the hole.

A number of shells were used almost in their original form, either with natural holes at the umbo or by breaking a hole through the shell's body. Specimens 5-11 illustrated in Figures 3 and 4 show both these practices in Acanthocardia tuberculata, Glycymeris glycymeris and Cerastoderma glaucum. The umbo-holes in the Acanthocardia tuberculata and Glycymeris glycymeris are quite worn and it is not clear

${ }^{10}$ Takaoğlu - Özdemir 2018, 489. 
from low power microscopy whether this was natural wear or a result of use.

The Cerastoderma glaucum were all broken by a blow to the body, and might have been used as a source of food. Most of these shells, which are complete, unholed, examples, were apparently leftovers from food as they were found in concentrations near hearths in certain parts of the settlement both in phases II and III at Gülpinar. Examination of the Cerastoderma glaucum shells demonstrates that some were also brought to the site in a naturally worn state, indicating that they were sometimes collected from beaches located nearby.

Our investigations on the shores around the shallow bays near Gülpinar also identified water-worn Cerastoderma glaucum shells with umbo-holes derived from natural breakages. It is possible that such shells might have been slightly modified before being used as beads/pendants or decorative items. A total of sixteen Cerastoderma glaucum shells with umbo-holes have been identified in phase II, and another twenty-four from succeeding phase III. Only three from phase III (Figs. 3-4: 8-10) are examined here because they all display similar features. The same argument also holds true for Glycymeris glycymeris shells, the natural-worn examples of which also turn up on the shore near Gülpinar. Thus, it is reasonable to argue that both shells left over from food and those collected from the shore, some with holes formed naturally, were probably sometimes used as personal ornaments by the settlers of both phases II and III.

A single example of a Phorcus sp. ring (Figs. 3-4: 12) shows little wear around its edges, except in one area where both edges are worn, perhaps from being suspended or having string tied around it. These rings of shell have an interesting distribution in prehistory that is discussed in more detail below. Likewise, a doublepierced moon shell (Cyclope neritea) (Figs. 3-4: 13) has parallels elsewhere, although examples are rare in archaeological contexts. The hole further away from the aperture is smooth around its edges and neat, the other is rougher. The shell is very fragile and would require quite gentle use.

There is a total of 11 examples of small Conus ventricosus shells, of a size to have no use as a source of food, among which are some with missing whorls such as item 14 in Figs. 3-4, which is a very worn shell. There is no obvious sign of string wear among these shells and it is possible that they were brought to the site for a variety of reasons, including use as beads but also possibly as gaming pieces, counters, or toys.

A piece of Ostrea edulis (Figs. 3-4: 15) has had a long hole punched through it, the hole has rough edges, with no indication of wear but there may have been an intention to make the shell into something as this is the only example where such a hole was made.

\section{Stone Beads}

The small number of stone ornaments was found in among the architectural debris of both phase II and phase III settlements at Gülpinar (Figs. 5$6)$. The single exception is Burial 1 in which there was deliberate deposition of three tiny beads (Figs. 5-6: 19-21). There is no indication of how these beads were strung or whether they were used in 
combination. The only pendant-form stone bead is a black perforated pebble (Figs. 5-6: 16). The hole was made from both sides and has a wide bevel suggesting slow and inconsistent drilling. The surface is polished, although this is probably largely the natural surface of the pebble.

The remainder of the stone beads consists of simple disc forms of various sizes. The largest of these (Figs. 5-6: 17) is made from serpentinite of a dark greenish grey colour in a long disc form. Another similarly large example (Figs. 5-6: 18) was made from basalt and has an obviously bevelled hole, a result no doubt of the difficulty of perforating this hard material. Three very small disc beads made from different materials (Figs. 5-6: 19-21), one turquoise in colour made from jadeite, another made from serpentine and a third tiny example made from limestone, make up the rest of the stone bead assemblage.

\section{Clay Pendant and Beads}

Clay beads came into use during the Neolithic period; most examples were simple, and often poorly finished and they rarely played an important role within the ornament repertoire ${ }^{11}$. The three clay beads from Gülpınar (Figs. 7-8: 22-24) do little to dispel this general reputation for low quality among clay ornaments. One of the beads (Figs. 7-8: 22) is larger and has a fairly smooth surface, although the shape is not very regular, the remaining two examples (Figs. 7-8: 23-24) seem to be expediently produced items with irregular shape and no attempt to finish the surface neatly. The holes were produced using a stick, which was pulled out of the clay

11 for discussion see Bains et al. 2013.

12 see Çakırlar 2009a. shape causing clay around one end of the bead to protrude and exaggerate the unevenness of the shape.

The use of clay to make pendants is even less common than its use in beads, probably due to the insufficient resilience of the fragile clay shapes if put into daily use. A single, broken, perforated clay form from Gülpinar (Figs. 7-8: 25) gives only clues about its original shape - perhaps a piece of figurine or a loop with a flat area at the top. The clay item was perforated as a secondary act, probably after the original item had broken, the hole was made from both sides and was achieved with slow drilling - probably a hand-held chipped stone. The broken edges of the clay piece are worn; although it is not clear whether this occurred pre or post repurposing. Although the shape is uneven, the surface finish is reasonably good when compared to the other perforated clay items, this probably relates to the item's original purpose.

\section{Discussion}

Factors affecting the collection and use of aquatic molluscs as ornaments have been discussed elsewhere, as has the natural quality of shells to serve as ornaments - often having holes caused by water wear or predation ${ }^{12}$. Indeed, recent research shows that not only are holes often naturally caused in dead shells by wave and sand/pebble action on the seashore but also that hole size is proportional to shell weight ${ }^{13}$. In the case of the Gülpinar assemblage we see a combination of deliberate manufacture

\footnotetext{
${ }^{13}$ Cabral - Martins 2016.
} 
and the expedient use of naturally preworn shells and pieces of shell.

Some of the shell ornaments at Gülpınar find parallels elsewhere. Phorcus rings are known from a number of sites of different periods, for example at Neolithic Franchthi Cave ${ }^{14}$, and at El-Qitar, Syria, in an Early Bronze Age tomb ${ }^{15}$ and the shell itself is also identified as a food source at sites such as Troy $^{16}$. A shared feature of the Phorcus rings is the apparent abrasion of the flat end surfaces of the ring and their obviously deliberate manufacture. These rings remain a rare but nonetheless geographically widespread enigma within ornament assemblages and were used over a period of several thousand years.

The use of perforated shell shapes such as examples 1 and 2 became widespread towards the end of the Neolithic and continued through the Chalcolithic $^{17}$. This adoption of larger forms seems to relate to a trend towards using more visible ornaments, often including the choice of materials of white colour, including marble, and with shiny surfaces, as seen in the use of mother of pearl.

The use of moon shells, and particularly those with two holes, one close to the aperture and the other situated roughly opposite the first, is becoming apparent as another practice that might be associated with the end of the Neolithic and the Chalcolithic at least in west and north-western Anatolia. Examples are

14 Jacobsen 1973; Reese 2016a.

15 Sagona 1986; Reese 2016b.

${ }^{16}$ Çakırlar 2009b. currently known at sites such as Aktopraklik.

The perforated pebble (Figs. 5-6: 16) can be compared to examples that are first seen in the Neolithic period in Anatolia in the form known by Stiner ${ }^{18}$ as the 'basket' and thought perhaps to have its roots in either naturally occurring shell forms such as Tritia gibbosula (formerly Nassarius gibbosulus) or the deer canine teeth that were popular as beads throughout prehistory. In general, the stone beads at Gülpinar show no features specific to the Chalcolithic period and would fit in terms of both typology and materials with much broader trends of bead use in Anatolia from the early Neolithic onwards ${ }^{19}$.

The use of ornaments at the site is also supported by the perforations seen in the clay figurines which indicate both ear and nose ornaments, although the form that these ornaments would have taken is unknown.

\section{Conclusions}

The site exhibits a range of ornaments from the simple use of natural resources in the form of water worn shells, to well-worked small stone beads. Although some wider comparisons can be drawn, the generally modest nature of the assemblage means that it has little to distinguish it as belonging to a particular period or region. Indeed, the stone beads are of generic types that belong to a long tradition within Anatolia that has its roots

\footnotetext{
17 see French 2010 and Baysal 2017 for examples from

Canhasan I.

18 Stiner 2014

${ }^{19}$ Baysal 2015.
} 
at least in the Neolithic, if not earlier. The shell items show more relation to later developments in ornamentation practices that started during the Late Neolithic and continued through the Chalcolithic. The clay beads, as is generally the case in prehistoric contexts, are unremarkable; they were made with little care and probably did not constitute an important element of ornamentation practices.

The number of personal ornaments in the assemblage is too low to argue whether there was any change in the use of objects such as beads and pendants during the occupation of Gülpınar. Indeed, most personal ornaments come from phase III at the site. The only statement that could be made is that there does not appear to have been a change in the use of holed Glycymeris glycymeris and Cerastoderma glaucum between phases II and III.

\section{Acknowledgements}

The authors would like to extend their sincerest thanks to Turan Takaoğlu for allowing them to study the artefacts and to David Reese for discussion of the shell bead assemblage.

\section{List of figures}

Figure 1: Map showing location of the site of Gülpınar.

Figure 2: Photograph showing the location of the prehistoric settlement of Gülpınar.
Figure 3: Beads of marine shell: Glycymeris sp. (1-2) Mytilus galloprovincialis pendant (3), Ceritbium vulgatum (4) Acanthocardia tuberculata (5), Glycymeris glycymeris (6-7), Cerastodermaglaucum (8-11), Conus ventricosus (12) Cyclope neritea (13) Phorcus turbinatus (14). Unfinished bead: Ostrea edulis (15).

Figure 4: Beads of shell: Glycymeris sp. (1-2) Mytilus galloprovincialis (3), Cerithium vulgatum (4) Acanthocardia tuberculeta (5), Glycymeris glycymeris (7), Cerastoderma glaucum (8-11), Conus mediterraneus (12) Cyclope neritea (13) Phorcus turbinatus (14).

Figure 5: Stone Pendant (16) from Building F, phase III; Bead from Building F, (17) phase III and (18) phase II; (19-21) from Burial 7, phase III.

Figure 6: Stone Pendant (16) from Building F, phase III; Bead from Building F, (17) phase III and (18) phase II; (19-21) from Burial 1, phase III.

Figure 7: Clay beads (22-24) from Building F, phase III. Fragment of a clay pendant (25), from Building F, phase III.

Figure 8: Clay beads (22-24) from Building F, phase III. Fragment of a clay pendant (25), from Building F, Phase III. 


\section{References}

Bains et al. 2013

Baysal 2015

Baysal 2017

Cabral - Martins 2016

Çakırlar 2009a

Çakırlar 2009b

French 2010

Jacobson 1973

Reese 2016b

Seeher 1987

Takaoğlu - Özdemir 2018
R. Bains - M. Vasi - D. Bar-Yosef Mayer - N. Russell - K. Wright - C. Doherty, "A Technological Approach to the Study of Personal Ornamentation and Social Expression at Çatalhöyük", in: I. Hodder (Ed.), Substantive Technologies at Catalböyük: Reports from the 2000-2008 Seasons, Volume 9 (London 2013) 331-363.

E. Baysal, "Neolitik dönem kişisel süs eşyaları: Yeni yaklaşımlar ve Türkiye'deki son araştırmalar”, TÜB $A-A R$ 8, 2015, 9-24.

E. Baysal, "Reflections of far away places: the Chalcolithic personal ornaments of Canhasan I", AnatSt 67, 2017, 29- 49.

J. P. Cabral - J. M. S. Martins, "Archaeological Glycymeris glycymeris shells perforated at the umbo: Natural or man-made holes?", JAS: Reports 10, 2016, 474 - 482.

C. Cakirlar, "Problems in determining the chain of production in shell objects: Observations on shell assemblages from coastal assemblages in eastern Mediterranean", in: R. de Beauclair - S. Münzel - H. Napierala (Eds), Knochen pflastern ibren Weg Festschriften Margarethe und Hans-Peter Uerpmann (Rahden/Westf 2009) 45-50.

C. Çakırlar, "To the shore, back and again: Archaeomalacaology of Troia", Studia Troica 18, 2009, 59-86.

D. French, Canbasan sites 3, Canhasan I: The Small Finds (London 2010).

T. W. Jacobsen, "Excavations in the Franchthi Cave 1969-1971, Part II”, Hesperia 42, 1973, 253-283.

D. Reese, el-Qitar (Syria) Shells. Unpublished report.

J. Seeher, "Prähistorische funde aus Gülpınar/ Chryse. Neue Belege für einen vor-trojanischen Horizont an der Nordwestküste Kleinasiens", Archaologischer Anzeiger 4, 533-556.

T. Takaoğlu - A. Özdemir, "The Middle Chalcolithic Period in the Troad: A New Look from Gülpınar", in: S. Dietz - F. Mavridis - Ž . Tankosić - T. Takaoğlu (Eds), Proceedings of the International Conference Communities in Transition: The Circum-Aegean Later Neolithic Stages (4500-3000 BC) (Oxford 2018) 479- 490. 


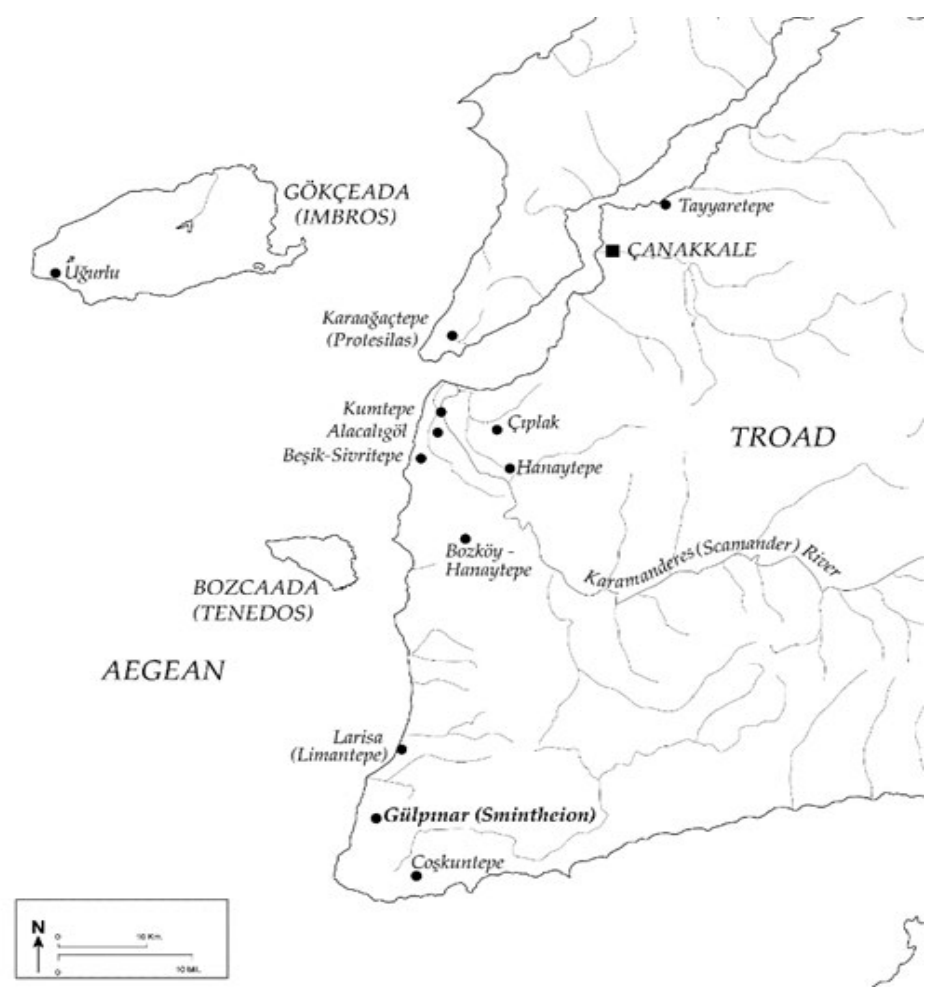

Figure 1

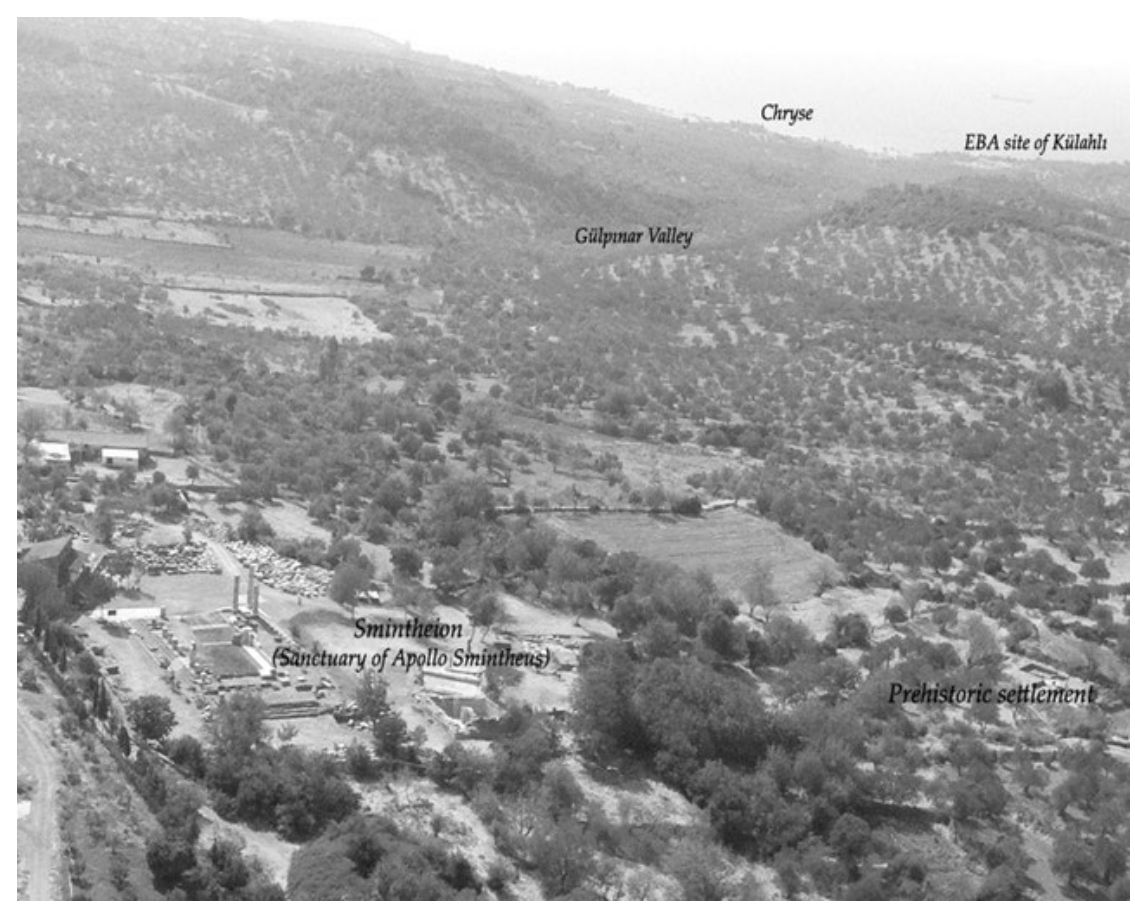

Figure 2 


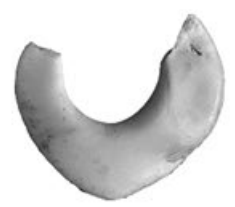

1

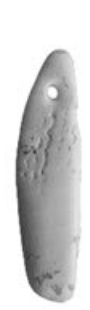

2

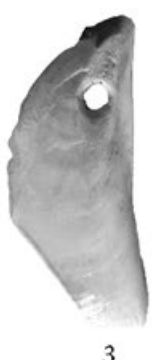

3

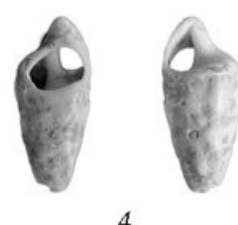

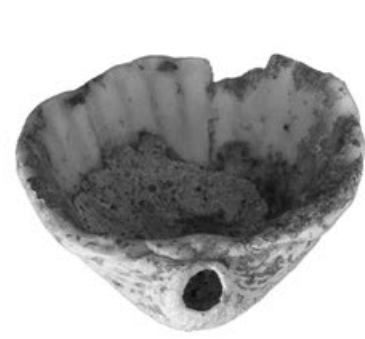

5

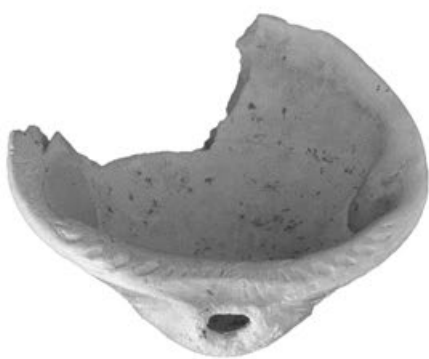

6

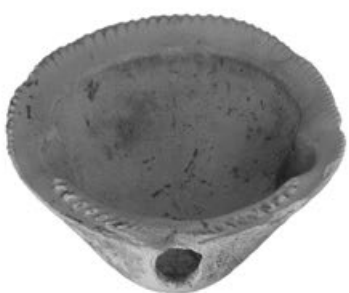

7

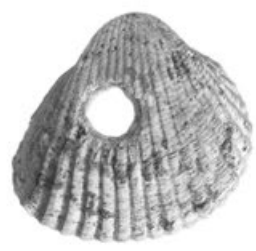

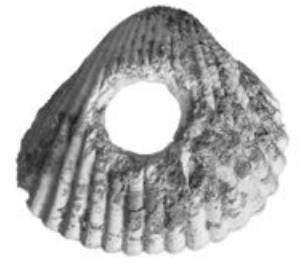

9

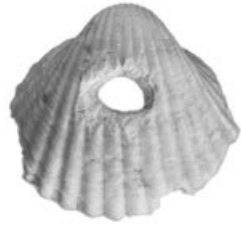

10

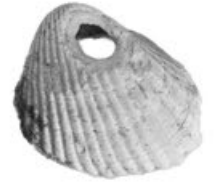

11

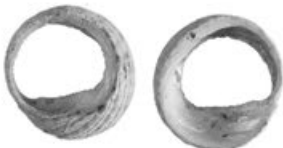

12

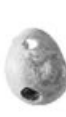

13

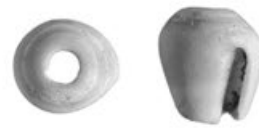

14 0

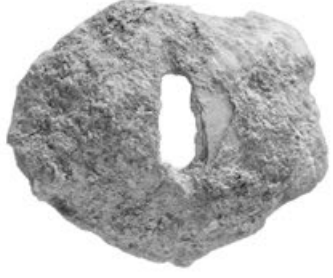

15

Figure 3 

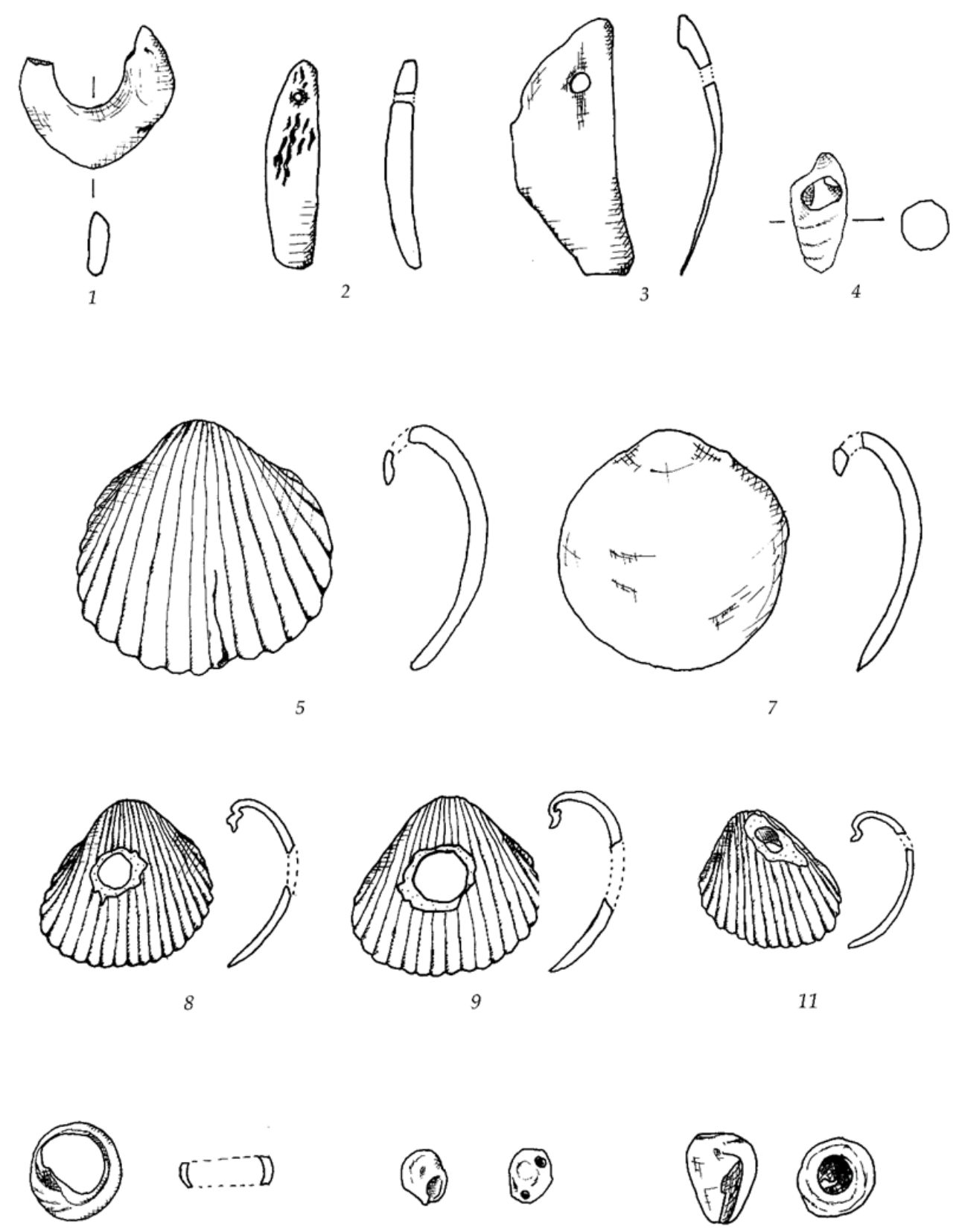

$(5 \cdots)$

(1)
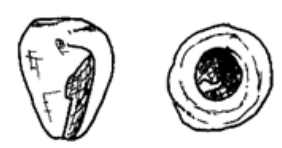

12

13

14

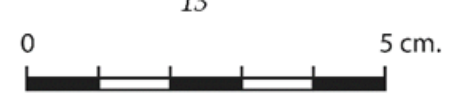

Figure 4 


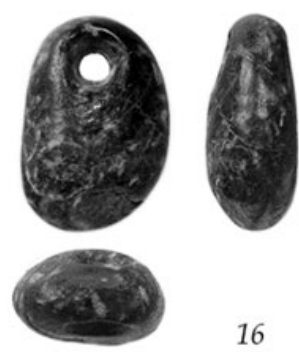

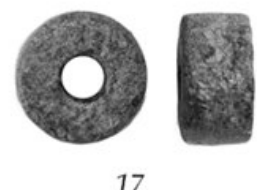

17

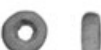

19

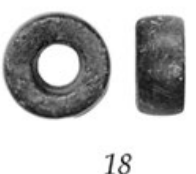

(6) 1

21

Figure 5
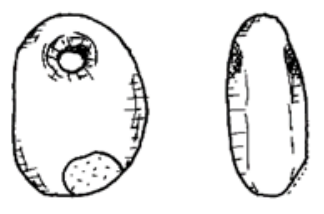

16

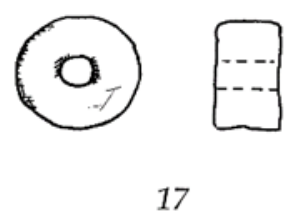

17
(0) $E$ 18
(2) 8

19
(0) $\mathrm{O}$

20

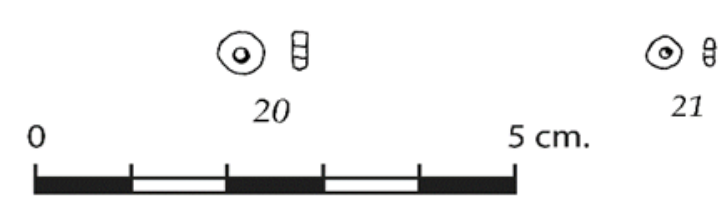

Figure 6 


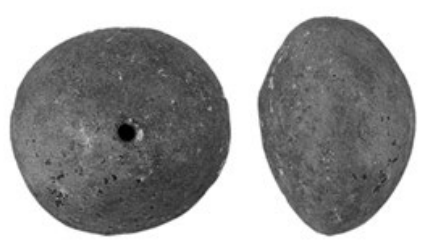

22

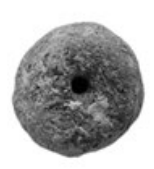

23
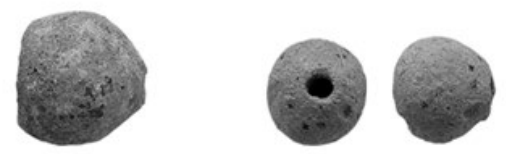

24
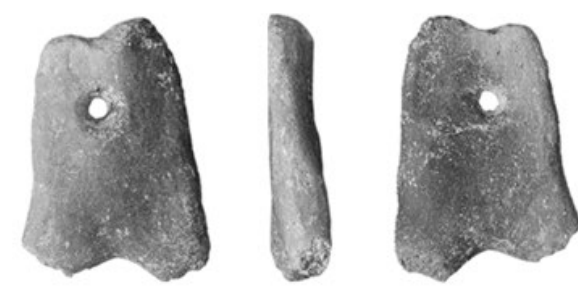

25

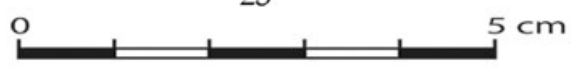

Figure 7

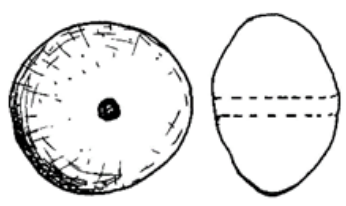

22

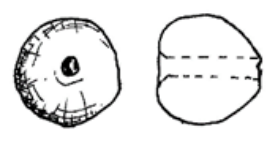

23
(2)

24

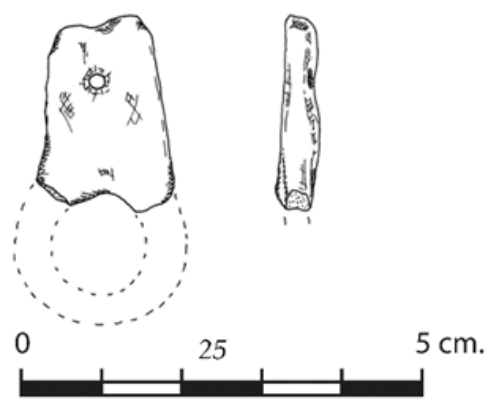

Figure 8 